\title{
Contributions of Social Networking for Innovation
}

\author{
Daniela Cartoni', Nanci Gardim², Sergio Caballero 3 , Marco Antonio Silveira ${ }^{4}$
}

\begin{abstract}
This paper investigates the role of virtual social networks as a mechanism complementary to formal channels of technology transfer represented by ICT and by private centers of R \& D in industry. The strengthening of Web 2.0 has provided the expansion of collaborative tools, in particular the social networks, with a strong influence on the spread of knowledge and innovation. To evaluate the potential of virtual networks, a survey had been conducted to identify and describe the characteristics of some of the major social networks used in Brazil (Linkedln, Orkut and Twitter). Even this phenomenon is not mature, the study identified the potential and benefits of social networks as informal structures that help in generation of knowledge and innovation diffusion, as a field to be explored and developed.
\end{abstract}

Keywords: social networks; innovation management; knowledge dissemination; management technology; knowledge management.

'Department of Graduate Studies. METROCAMP College - Ibmec Group. Rua Dr. Sales de Oliveira, I66I -Vila Industrial, Campinas - Brazil - Zip Code I3035-270.(55)I9 450I2632. E-mail: daniela.cartoni@metrocamp.edu.br

DTSD-G.A.I.A./ Support Group for Innovation and Learning in Organizations, CTI-MCTI/Center for Information Technology Renato Archer, Rod. Dom Pedro I km I43 - Campinas - Brazil - Zip Code: I3069-90I - (55) I9 37466083.

²E-mail: nanci.gardim@cti.gov.br, ${ }^{3} \mathrm{E}$-mail: sergio@caballero.com.br, ${ }^{4} \mathrm{E}-\mathrm{mail}$ : marco.silveira@cti.gov.br 


\section{Introduction}

With the advancement and consolidation of Web 2.0, the use of collaborative tools - especially for virtual social networks - has established itself as a trend, which prints new features to the way people understand and experience different aspects of their lives.

In recent years, various countries staged events that reveal the potential permeability of articulation of different virtual social networks. They also show how much can be comprehensive - through intense mobilizations in favor of "single causes" - virtual social networks highlight new interactions between individuals and groups, and new approaches to the spread of knowledge and innovation.

In this perspective, different authors (Vasconcelos \& Campos, 20 I0; Tomaél,Alcará \& Di Chiara, 2005) argue that informal social networks are important sources for the promotion of innovative activity. Such networks maintain channels and information flow in which the reliability and respect between co-workers lead them closer to the sharing of knowledge held by them.As noted by Nonaka and Takeuchi (1997), informal social networks are important because they allow knowledge flow, which in turn needs to be transformed, developed and worked by organizations, otherwise it would be just an aggregate of irrelevant information.

Assuming that social networks act as a complement to formal actions for technology transfer - both developed by ICTs (Institutes of Science and Technology) and those developed by companies that invest in research and development - this study aims to identify and describe the potential of some of the major social networks used in Brazil (Linkedln, Orkut and Twitter) and informal structures that help knowledge generation and diffusion of innovation.

This study is part of a more comprehensive project, aimed at developing and deploying an corporative gateway (portal) from a research group called GAIA (Support Group for Innovation in Learning and Organizational Systems). The portal - supported by National Counsel of Technological and Scientific Development (CNPq) and ongoing at the Center for Information Technology Renato Archer (CTI), in Campinas / SP / Brazil - is focused on the management of intellectual capital for sustainability of organizational systems. It aims to integrate not only data, but also the different actors responsible for innovation in the country, namely, educational institutions / research (public and private), business, government, and various multipliers (such as academics and entrepreneurs). The use of the virtual social networks in promoting innovation will help build a communication plan to facilitate an appropriate interaction of the portal with these networks.
In addition, the prospecting of key points (themes and processes) to be better exploited within these social networks can collaborate in the planning of new actions for the dissemination of scientific knowledge, both accumulated by GAIA-CTI and by partner institutions.As stressed by Araújo (1979), information about a particular project can be disseminated through informal channels even before it is started. This disclosure, according to the author, is usually performed by means of informal communication network in which the researcher is inserted. In this context, we bring the second point of this article some assertions about the relationship between technological innovation and social networks for informal communication, in sequence,, align some insight into the concept of "virtual social networks (informal)" and the main theories that permeate the analyzes of the subject.

Although the study is not conclusive, we present how the main social networks in Brazil - Orkut, Linkedln, Facebook, and Twitter - deal with innovation promotion. We will verify the proposition that social networks, based on the interdependent relationship between the actors, stand as a relevant tool for the sharing of expertise and for the generation of technological innovation.

\section{Technological Innovation and Informal Communication Networks}

The role of human capital in the cross organizational sharing of technology is becoming more widely recognized, allowing a different look at the various ways and means by which "knowledge transfer" develops (Bozeman, 2000). In general, informal social networks - such as those that form spontaneously in everyday relationships, mediated or not by the Information and Communication Technologies (ICT) - are more flexible and less deterministic than the organizational and inter-organizational networks, which are always subject to different degrees of formalization. In this context, for the transfer of relevant technical information, personal contacts stand out as being those for whom the technology is more efficiently adopted (Araújo, 1979).

Informal social networks affect, more incisively, the extent to which the individual learns and internalizes the rules involving the social and organizational context. What is really new is the way the networks and/or informal relationships are being established; in other words, which "communication patterns" are valid. The works that emphasize the analysis of intra-organizational informal networks - such as Cross and Prusak (2002) and Silva (2003) - have in common the view that informal networks are invisible and powerful tools for innovation managers. From this perspective, it is understood that knowledge is inherent in people, but its transmission occurs with the implementation of mechanisms for sharing - 
since the purpose of social networks is sharing and this can be applied to Knowledge Management.

The channels and informal social networks are very efficient from the perspective of the direct interaction between the information source and the information consumer.They enable researchers to accelerate the discovery of similar problems, whether issues discussed are of mutual interest, and also allow them freer speculation about the research they are doing, more productive processes and methods, and their successes and failures (Garvey and Griffith, 1967)

Disagreements in perspectives based on profession and the resulting difference in the nature of the research and products among the various industry professionals and academics, generally, have implications for those interested in sharing information for any of the activities. However, the most important factor when looking at techno-scientific communication conveyed through channels and/or informal social networks is "the time of dissemination of information," which most often begins even before the project starts (Araújo, 1979).

With the spread of ICTs, the speed of the exchange of information (formal and informal) rose sharply, but did not alter the already established scene. The informal relations still spread knowledge faster than formal networks. The internet, as a "network of networks" with e-mail services, communities of practice (such as forums, wikis, blogs and social networks), facilitates interaction between researchers and practitioners from various fields of Science and Technology. The informal channels reveal higher value-added to information, useful both for decision making and for creation of arising strategies from information not published yet. Martins (et al, 2009) emphasizes that social networks are the key to transforming the individual resources into organizational resources.

Although the channels and informal sources are unstructured and unorganized in the online environment, different authors - among them Rizova (2006) and Vital (2006) - understand that they are primary sources of information, especially for dynamic technology intensive companies which have as one of their greatest assets the knowledge of their teams of researchers (and their constant improvement).

\section{Conceptualizing Social Networks}

One of the most striking features of the information society is searching for individuals with a broad and varied spectrum of skills, who built a reputation, both individually and by their ability to interact in networks (Castells, 1999). It is in this sense that skills are associated with performance in dynamic environments, from building relationships based on abstract processes, as well as making decisions, working together, and adapting to expanded horizons of space and time, breaking up with traditional elements like distance and synchronicity (Lévy, 1998).

In this context, the network configuration - already peculiar to the human being as a way to promote grouping with their peers and gather people or groups with shared interests and values - takes on new characteristics and social relevance. The networks go beyond the limits of personal relationships and extend itself in the organizational or institutional aspect, and may also be appropriate for organizations as a channel to support search and generation of innovation.As explained by Marteleto (200I, p. 8 I),“(...) although born in a sphere of informal social relationships, the effects of networks can be perceived outside their scope, interactions with the state, society, or other representative institutions ".

The concept of networks presupposes clusters, and consequently, represents collective phenomena. They do not necessarily bind to a geographic community or hierarchical, but generally exhibit non-linear structure, decentralization, self-organization, and have base in horizontal cooperative relations (Barnes, 1987; Tomael, 2005).

According to Hanneman (2004), the basic idea of a network is simple: a group of actors (nodes, agents, or points) among which there are links (or relationships). The understanding of its operation has as its central axis the interactions between actors, not privileging individual evaluations from the profile of the individual, but his relations with the context. "[...] the position of each individual in the network depends on the informational and social capital that one can add to themselves and to all" (Marteleto e Silva, 2004, p. 42).

Networks can vary in scope, size and heterogeneity. The higher the social network the more heterogeneous are the social characteristics of network members and greater the complexity of its structure (Toamel, 2005).

As emphasized by Aguiar (2006), a social network is comprised of two main elements: the structure and the dynamics. The structure refers to the components of the network, which consists of actors and groups of actors, through information sharing and knowledge construction. These are represented by "node" who are part of a larger system of interaction and social ties. They act directly in the creation of communities that make up the so-called clusters or clicks, from the construction of roles that will establish links between the actors. Another element is the dynamic, i.e. how relationships occur across the network, characterized by the pattern and pace of information flow of connections between the actors, the degree of participation of the members of the network (frequency and quality with which 
they communicate) and the effects of participation on other members and on network development.

From the analysis of these elements is possible to map how the social network is set up and understand their impact on the processes and institutions in which it operates. According Barabási (2003), the understanding of networks is vital not only for routine activities, but also in business and science. Identifying how the dissemination of knowledge permeates our academic environment is one way to contribute to the already existing relations to be expanded, new ones created, and to think about the formation of a structured network for the development of common knowledge.

\section{Theories About Social Networks}

The research and theories about social networks have pretty broad scope. The theories developed in distinct stages, from concept originated from the Social Sciences and later integrated to the work coming from Graph Theory (Viana, 2004).

In recent years, the concept of network has been observed more carefully, especially in regard to its application to complex systems and in virtual space, although its approach is not new . According to Aguiar (2006), trajectory studies of social networks in the international academic scene can be divided into four key stages:

a) The period between the years 1930 and 1970 in Social Psychology, Anthropology, and Sociology, markedly with influence of structuralist and functionalist approach. There is a predominance of the sociometric analysis of social organizations, the quest for identifying patterns of interpersonal bonds in specific social contexts, and the research of the structures in group relations;

b) Between 1970 and 1990, with the development of "Social Network Analysis" not only as a research specialty in Social Sciences, but with the support of computer programs and application of mathematical language in developing highly technical and quantitative methodologies.

c) The emergence of multidisciplinary research motivated by the increasing complexity of social relations and the computer-mediated communication since the mid-1980s, in which network metaphors are taken as basis for analyzing information flow through the interactions between people, human groups and organizations, under strong influence of systems theory;

d) The current phase, in which the social network analysis is sophisticated with the support of various computational tools and more accessible techniques. Analyses on the cyberspace address the differences between various groups and their impact on individuals, in the context of a globalized macrostructure of interpersonal, organizational, and community network, connected to the Internet.

Currently, it is undeniable that social networks have grown dramatically in the creation of networks, driven by the use of software with friendly interface and integration capabilities of the information technology that allow us to invite friends, colleagues, customers, suppliers, and others in the network of personal and professional contacts. They can be used both to bring people with specific interests and for social relationship in the academic and scientific sphere. They are, in short, environments that enable the formation of interest groups that interact through common relationships.

For this article, virtual social networks and their impacts on information sharing and support on the construction of knowledge essential to the innovation process will be analyzed.

\section{Trust and Reputation in Virtual Social Networks}

In dealing with social networking on the Internet, the structure of connections and types of links between the actors should be considered in the analysis. In the aspect related to sharing information, it is considered that, apart from the possible altruism by individuals that like to share what they know, there is a fundamental interest in the reciprocity (obtaining information generated by group) and confidence. Similarly, the construction of knowledge will only bring results if it involves a learning process, for the simple access to information does not change the reality (Toamel, Alcara and Di Chiara, 2005).

A related concept to social networks that has obtained space in organizational literature is the "social capital", which is positively related to knowledge dissemination and generation of innovations. The term refers to a type of capital that can generate competitive advantage for individuals or groups connected to certain networks, i.e. are better related due to participation and access to information (Martins et al, 2009).

As stated by Recuero (2009), the type of connection in the social network influences the process of disseminating information, which may be based as much on mutual social interaction, with a relational membership, as in the reactive social interaction, with a membership association based solely on the position as a member of the network. In other words, the author explains that social interactions formed on the internet can be based both on the appropriation of technology by the actors and on interactive links.

ISSN: 07 I8-2724. (http://www.jotmi.org)

Journal of Technology Management \& Innovation (c) Universidad Alberto Hurtado, Facultad de Economía y Negocios. 
The mutual social interaction in virtual networks is based on exchanges between group membership and characterized by the relational feeling of "being part of", through communication exchanges. As an example, we have communities that emerge through blogs, where you need to exchange comments and create links so that they receive support and social capital. This type of interaction has high maintenance cost, since social actors need to invest in message exchanges, as well as time spent in conversations on MSN, discussion forums or themed publication of tweets. Because of these features, the connections are tighter, working based on trust and social support.

Now, in reactive social interaction, membership is based on the identification of the actor with the topic dealt in the group, more than in the social interaction that takes place in that space. This type of bond implies in a low maintenance cost for the actor, where all that is needed is to join in the net and all values of the network become immediately accessible. This association, however, is motivated by a process of identification between user and group, i.e. the construction of identity and self-definition in virtual space binds to this accession as a mechanism for creating empathy in winning new friends. This is what happens, for example, with communities on Orkut, where more than to interact, actors are affiliated to the group to show certain common interest or idea in your profile, resulting in a membership association, whose ties do not wear out, such is the case of many communities that have hundreds of users and little interaction (Recuero, 2005).
These networks based in the reactive interaction have weaker ties between actors. Due to the low cost of belonging to these groups, it is clear, too, that it is possible that the same actor is part of several networks. As no investment is required for their maintenance, they can be sustained until one of the parts decides to end the connection (Souza, 2010).

In terms of the circulation of social capital in networks, there are clear differences. In the case of prevalence of mutual interaction, as they are comprised of bonds, they are stronger, smaller, and have a well-defined nucleus, where reciprocity is more evident. These networks are maintained by the actors' interest in making friends and fostering ties, which leads to higher quality of "relational capital" in circulation (Recuero, 2009).

On the other hand, in the case of network focused on reactive interaction, membership is based on the identification, by subject, construction of identity, demonstration of tastes, and preferences (Bertolini and Bravo, 2004). The integration allows members to enjoy information disclosed to members, which brings greater emphasis on "informational capital" because the information has value for the formation of reputation or for the primacy in the dissemination within a particular interactive community.

This differentiation is essential as it allows us to understand that social networks are not all alike and that their structural differences interfere directly in the dissemination of information through their connections.

\begin{tabular}{|l|l|l|l|l|}
\hline Keywords Related to Innovation & $\begin{array}{l}\text { Facebook } \\
\text { Groups in } \\
29 / 5 / 20 I I\end{array}$ & $\begin{array}{l}\text { Linkedln } \\
\text { Groups in } \\
05 / 5 / 20 I I\end{array}$ & $\begin{array}{l}\text { Orkut } \\
\text { Community in } \\
\mid 4 / 5 / 20 I I\end{array}$ & $\begin{array}{l}\text { Twitter } \\
\text { Tweets }(*) \text { in } \\
09 / 5 / 20 I I\end{array}$ \\
\hline Innovation & 477 & 172 & 449 & $>=1000$ \\
\hline Technology & 257 & 980 & $>=1000$ & $>=1000$ \\
\hline Technological Innovation & 0 & 13 & 15 & 8 I \\
\hline Technology Transfer & 2 & 13 & 0 & 16 \\
\hline Patents & 4 & 18 & 78 & $>=1000$ \\
\hline Intellectual Property & 21 & 11 & 8 & 91 \\
\hline Institutes and Research Centers & 0 & 0 & 0 & 0 \\
\hline Research Institute & 14 & 21 & 15 & 84 \\
\hline Research Center & 5 & 7 & 46 & 34 \\
\hline Research & 275 & 165 & $>=1000$ & $>=1000$ \\
\hline R\&D & 0 & 7 & 46 & $>=1000$ \\
\hline R\&D & 57 & 0 & 294 & $>=1000$ \\
\hline Research and Development & 11 & 31 & 2 & 22 \\
\hline
\end{tabular}

Table I: Social Networks and Frequency of Keywords Related to Innovation

(*)Text messages from Twitter.

ISSN: 07I 8-2724. (http://www.jotmi.org)

Journal of Technology Management \& Innovation (c) Universidad Alberto Hurtado, Facultad de Economía y Negocios. 


\section{Brazilian Virtual Social Networks and Innovation Promotion - Method}

Based on the research question about the contribution of social networks to the spread of knowledge and innovation support, we consider in our study the following networks: Facebook, Linkedln, Orkut and Twitter. The choice of these is justified by the fact that they are the most popular social networks in the country, both in terms of number of participants and accesses. According to the website Alexa, which measures the rate of access to web pages, this is the overall ranking of access to sites in Brazil: Ist Google Brazil, 2nd Google, 3rd Facebook, 7th Orkut Brazil, 14 Twitter, 26 Linkedln. Orkut in Brazil, which used to be the leading social network, lost the post to Facebook earlier this year 2011 (Alexa, 20I I).

Considering the report 2009 Business Social Media Benchmarking Study (Hanna, 2009) based on research conducted in the United States with business professionals, on average, companies have profiles on three social networks - social networks in which the largest number of companies have profiles (among I,197 respondents) are: Facebook: 80\% Twitter: 56\% Groups on Linkedln: 39\% Orkut: not listed (it has little relevance in the United States). From this context, it was initially considered that this could be repeated in the Brazilian scenario. However, as the intention was to understand how social networks were contributing to the exchange of technical and scientific information specifically, and not just with the promotion of institutional marketing, we chose to start the research looking for words or key phrases to the theme of innovation within networks .

With focus specifically on the existing Brazilian social networks groups Facebook, Twitter, Linked In, and Orkut, the words and key terms selected for the search were: Innovation, Technology, Technological Innovation, Technology Transfer, Patents, Intellectual Property, Institute of research, Research Center, Research, R \& D, R \& D, and Research and Development. Understanding that these are expressions very recurrent among researchers and innovation managers, the goal was the initial survey on the number of communities and discussion groups that addressed issues related to innovative activities (see Table I).

\section{Design and Procedure}

Some practical difficulties were found during the survey. One was the emergence of impracticable or imprecise terms to be applied to quantitative research for the following reasons:

a) Numbers and results

The social network that allowed access to a search system appropriate to the aims of this research was Linkedln. When using a search term, the total number of groups associated with the term is shown, regardless of the amount of existing groups. Orkut also shows the total number of groups at their interface, but with the limit of 1000 results indicating that there is a number higher than this result. Facebook's search system shows only 10 results, without indicating what would the total be.

To see more results, it is necessary to press a button and 10 more results are shown. Twitter also does not show the total, you have to navigate to the page footer so that more results are shown. Furthermore, within the Twitter, as a network in which messages are posted by users very dynamically, most popular terms, such as "technology", showed 10 new results per minute.

\section{b) Filtering results}

There is a need to filter the results shown, due to polysemy that some terms have, or in other contexts that they can be employed. "Technology" and "research" showed many results within Twitter, Orkut, and Facebook, which have no relation to the subjects of this study.

We cite as examples: in Orkut such communities are found "I'm addicted to technology" and "Just do research on Wikipedia." Other terms such as $P$ \& $D$ and $R$ \& $D$ showed several communities and Tweets that have the letters $R \& D$ with other varied meanings. For example, on Orkut, $R \& D$, among the 46 results, only 7 actually refer to the term "research and development".

After verification of the restrictions imposed by the problems described above, and considering that Linkedln has a

\begin{tabular}{|l|l|l|l|}
\hline Group & Theme & Members & Focus \\
\hline A & Network Design and Innovation Management - Brazil & 943 & Design and Innovation \\
\hline B & Innovation for Sustainability & 375 & Design and Innovation \\
\hline C & Innovation Community & 356 & Innovation \\
\hline D & PMI São Paulo & 5737 & Project Management \\
\hline
\end{tabular}

Table 2:Theme, number of members and focus of groups surveyed

ISSN: 07 I8-2724. (http://www.jotmi.org)

Journal of Technology Management \& Innovation (c) Universidad Alberto Hurtado, Facultad de Economía y Negocios. 
stated focus in the professional scope, showing better search tools and organization, it was decided that further research on the users would be restricted only to existing groups in this social network. Because it is the term that best identifies the purpose of the research, the word "Innovation" was chosen to carry out searches in groups.

\section{Results}

After defining keywords related to innovation, research has focused the three groups with the largest number of members and search results (for the word Innovation) were selected for analysis. Groups were designated A, B, and C, we chose to compare to a control group D (see Table 2).

The messages exchanged publicly in groups of 4 for a month (25/04/20 I I to $25 / 05 / 20$ I I) were analyzed and divided into 4 categories: * Category I:Technology Solutions Proposals; * Category 2: Divulgation of Congresses and Events; * Category 3: requests for guidance or technical inquiry; ${ }^{*}$ Category 4: Other (business ads, issues not directly related to Innovation and Projects). The result of the classification of messages is shown in Table 3.

Note that in groups $A, B$, and $C$ there is greater emphasis on the Divulgation of Congress / Events or Other (business ads, issues not directly related to or Innovation Projects). In the control group $D$, the emphasis is on requests for guidance related to career, team motivation, estimated project cost, among others.

To filter the results, a performance indicator between "requests for guidance or technical inquiry " and " requests for guidance or answered technical inquiry " was created, this way we generate a meter: Response Efficiency $(R E)=(a n-$ swered questions / inquiries made).

In comparison with group of Project $D$, there is a significant difference in both the amount of inquiries made and in the Response Efficiency (RE) of the requests for guidance or technical inquiries made between groups of Innovation A, B, and $\mathrm{C}$, according to Table 4.

The members of group of Project $D$ seem to give greater emphasis to the need for creation of reputation with the professional group, interacting both with questions and answers. Now, members of groups $A, B$, and $C$ do it on a smaller scale, we noted the participation of more companies seeking to establish a position of prominence within these groups.

During the research another practical difficulty came up: A structured questionnaire was not used to draw a profile of the users of these groups in a qualitative analysis. However, due to the low response rate to the questionnaires, they were discarded for lack of statistical significance.

One possible explanation for this behavior can be found in the literature, as highlighted by Recuero (2004) in the analysis of the links established in the networks and reciprocity as social capital (Marteleto and Silva, 2004). Groups A, B, and C fall as networks of reactive social interaction, characterized by low circulation of capital and low reciprocity in communication processes, which can be illustrated by the low volume of questions and answers. The members seem to participate only to have access to information or to define their iden-

\begin{tabular}{|l|l|l|l|l|}
\hline Grupo & $\begin{array}{l}\text { Proposals and Tech- } \\
\text { nological Solutions }\end{array}$ & $\begin{array}{l}\text { Academic Congresses } \\
\text { and Events Divulgation }\end{array}$ & $\begin{array}{l}\text { Requests for Guidance } \\
\text { or Technical Inquiries }\end{array}$ & Other \\
\hline A & $12,0 \%$ & $48,0 \%$ & $12,0 \%$ & $28,0 \%$ \\
\hline B & $28,1 \%$ & $22,0 \%$ & $3,7 \%$ & $46,3 \%$ \\
\hline C & $8,3 \%$ & $8,3 \%$ & $5,6 \%$ & $77,8 \%$ \\
\hline D & $6,3 \%$ & $6,3 \%$ & $81,3 \%$ & $6,3 \%$ \\
\hline
\end{tabular}

Table 3: Classification of messages from the surveyed social networks

\begin{tabular}{|l|l|l|l|}
\hline Groups & Inquiries Made & Inquiries Answered & Response Efficiency \\
\hline A & 3 & 2 & $66,7 \%$ \\
\hline B & 3 & I & $33,3 \%$ \\
\hline C & 2 & I & $50,0 \%$ \\
\hline D & 13 & II & $84,6 \%$ \\
\hline
\end{tabular}

Table 4: Response Efficiency to Inquiries made in the Groups

ISSN: 07 I8-2724. (http://www.jotmi.org)

Journal of Technology Management \& Innovation (c) Universidad Alberto Hurtado, Facultad de Economía y Negocios. 
tity in the group, either for the affairs of the community or to create a profile associated with specific activities or preferences.

As a way to establish a minimum profile of participants in the groups, we used data provided by the participants in the field of user profile on Linkedln, related to the sector of professional activity. It was observed, then, that in all groups there was a large percentage of participants who did not report the sector of professional activity which comprises: Group A: $45.49 \%$, Group B: $51.47 \%$, Group C: $49,72 \%$, and group D $35.05 \%$. Table 5 presents the three sectors that most participate in each of the groups:

It can be observed that the groups are formed by professionals directly linked to the area of interest of each group. As an example, one can cite group A (Network Design and Innovation Management), where the majority of members belong to the sector and are active in the area of Design, as well as the Group B (Innovation for Sustainability), where the majority of members belong to the sector of Environmental Services.

The Management Consulting industry came up as one of the three most important in all groups related to Innovation, professionals working in this sector seem to be the ones that invest in the creation of social capital, so that they can create competitive advantages for participating in these groups (Martins et al, 2009). In Project group (D) the sector with the largest share is the information technology and services.

It can be argued that there are opportunities for change in the quality of relational aspects within the Innovation group $A, B$, and $C$ analyzed in this study when compared with the control group D. One could cite the increased social interaction by the increase of mutual discussions in the groups with the consequent increase of circulating capital in these groups.

As noted previously, a big part of the associated groups A, $B, C$, and $D$ do not inform their industrial sector, but you can see that even in this regard Project group $D$ shows superior performance compared to groups $A, B$, and $C$ in this research. This approach also seems to reflect an investment in the social and informational capital (Marteleto and Silva, 2004, p. 42), higher in group D than in Project Innovation groups A, B, and C.

It is observed that there is room for improvement in the use of social networks to the spread of knowledge and innovation, because the innovation groups considered are still, generally, utilized to publicize events and news. There is little use for inquiries because of its low return in opposition to the Project group, where members focus more on questions and a higher degree of efficiency in the answers occurs. Thus, groups of Innovation A, B, and C have a reactive interaction where the biggest social capital is information (Betolini and Bravo, 2004) unlike Project group D where capital seems to be both information and mutual interaction (Recuero, 2009).

\section{Discussion}

The literature shows that informal channels of communication are widely used by researchers - scholars, research institutes, and private organizations - for the exchange and sharing of technical and scientific information. With the advent of the internet and interactive possibilities arising from the Web 2.0 applications, relationships that previously depended on the concentration of people in the same space, were able to break the geographical boundaries. Among the different forms of computer-mediated communications, social networking has been shown effective for mobilizing individuals linked to several issues. However, regarding specifically the promotion of innovation, some considerations on the Brazilian social networks are necessary.

Although the results of the research presented in this paper are still partial and inconclusive, it was noted that support for innovation diffusion within social networks - Twitter and Facebook - is basically ruled on the disclosure of institutional events in the area. For sharing technical and scientific information, however, these social networks have not shown maturity and deepening in the connections among actors for fruitful exchange of knowledge.

In Linkedln's case, there is a potential to be developed in the exchange of technical information, much higher than other networks studied. The stronger propensity for innovation support is due to the fact that it is based on the professional profiles of its members. The search for specific interests in social networking privileges the strengthening of a reputation in a particular field of knowledge or between peers.

Another factor which confirms the potential of Linkedln in stimulating innovation is the fact that larger informational capital circulates in this network, while Twitter is merely informative and networks like Orkut and Facebook basically regard the relational capital (personal ties and friendship, without much interactivity for discussion of innovation or professional topics related to it). It was observed in a group that congregates project management professionals, the intensive exchange of technical knowledge, which demonstrates the ability of the network to be used also as a tool for the diffusion of innovation.

As a result, the hypothesis that social networks act as a complement to formal actions for technology transfer should 
be seen as a potential to be explored in order to propitiate an effective diffusion of knowledge on topics related to innovation.

Even incipient, diffusion knowledge process through social networks shows its possibilities to strengthen in the coming years. Future studies can explorer the changes brought about by new networks that are highlighted and what the dynamics of the processes, both in topics relevant and researchers profile.

\section{Acknowledgments}

The authors thank to the efforts of various professionals and institutions that contributed to the viability of this project. We highlight the contributions made by Felipe Orsini Martinelli.

\section{References}

AGUIAR, S. (2006). Redes sociais e tecnologias digitais de informação e comunicação no Brasil (1996-2006). Relatório final de pesquisa. NUPEF Rits - Núcleo de Pesquisas, Estudos e Formação da Rede de Informações para o Terceiro Setor.

ALEXA. Disponível em: < http://www.alexa.com/topsites/ countries/BR>. [Acessed July 2I, 20II] ARAÚjO, V. M. R. H.(1979). Estudo dos canais informais de comunicação técnica: seu papel na transferência de tecnologia e na inovação tecnológica. Ci. Inf. Rio de janeiro, v. 8, n. 2, p. 79-100.

ARAÚJO, V. M. R. H., Freire, I. M. (1996). A rede internet como canal de comunicação, na perspectiva da ciência da informação. TransInformação. v. 8, $n^{\circ} 2$, pag. 45-55, maio/agosto. <http://atbibliofurg20I I.files.wordpress.com/2009/05/arede-internet-como-canal-de-comunicacao.pdf>. [Acessed July $2 \mathrm{I}, 20 \mathrm{II}]$

BARABÁSI,A. L. (2003). Linked: How Everything Is Connected to Everything Else and What It Means. Plume Publishing.

BERTOLINI, S., Bravo, G. Social Capital, a Multidimensional Concept. http://www.ex.ac.uk/shipss/politics/research/socialcapital/other/bertolini.pdf. [Acessed July 2I, 20I I]

BOZEMAN. B. (2000). Technology transfer and public policy: a review of research and theory. School of Public Policy, Georgia Tech, Atlanta, GA 30332 USA. Elsevier Science B.V.

HANNA, B. (2009). Business Social Media Benchmarking Study Media.
CASTELLS, M. A. (1999). Sociedade em rede. 4 ed. Rio de Janeiro: Paz e Terra.

CROSS, R.; Prusak, L.; Parker, A. (2002). Where work happens: the care and feeding of informal networks in organizations. Cambridge: IKO. <www-304.ibm.com/jct0300 Ic/ services/learning/solutions/pdfs/iko_wwh.pdf>. [Acessed July $2 \mathrm{I}, 20 \mathrm{II}]$

DONATH, J. S. (1999). Identity and Deception in the Virtual Community. In: KOLLOCK Peter. e Marc Smith. (org.). Communities in Cyberspace. Routledge. New York.

FREEMAN, L. C. (1996). Some antecedents of social network analysis. Connections, v. 19, n. I, p. 39-42.

GARVEY,W. D.; Griffith, B. C. (1967). Scientific communication in social system. Science, 157, p.1011-1016, setembro. http://www.sciencemag.org/content/I57/3792/I0I I.full.pdf. . [Acessed July 2I, 20II]

GOOGLE Trends. http://www.google.com/trends. [Acessed July $2 \mathrm{I}, 20 \mathrm{II}]$

GRANOVETTER, M. (1973). The strength of weak ties. American Journal of Sociology, Chicago, v. 78, n. 6, p. I3601380, maio, 1973. http://ejournals.ebsco.com/direct.asp?Arti cleID=4C8EB6FB894 I 8FF97088 [Acessed July 2I, 20II]

HANNEMAN, R. A. (2004). Introducción a los métodos del análisis de redes sociales. Revista Redes, 2004. < http://revista-redes.rediris.es/webredes/> [Acessed July 2I, 20I I]

LÉVY, P.(1998).A inteligência coletiva. São Paulo: Loyola.

MARTELETO, R. M. (200 I).Análise de redes sociais: aplicação nos estudos de transferências da informação. Ciência da Informação. Brasília, v. 30, n. I, p. 7I-8I, jan./abr., 200I. http:// www.scielo.br/scielo.php?script=sci_abstract\&pid=SO I00$9652001000100009 \& \mid n g=p t \& n r m=i s o \&$ tlng $=p t \quad$ [Acessed July $2 \mathrm{I}, 20 \mathrm{II}]$

MARTELETO, R. M., Silva, A. B. O. (2004). Redes e Capital Social: o enfoque da informação para o desenvolvimento local. Ciência da Informação, v. 33, n. 3. http://revista.ibict.br/index. php/ciinf/article/view/5I8 [Acessed July 2I, 20I I]

MARTINS, G.J.T., Quincozes, E. R. F., Pereira, M. F., Fialho, F.A. P. (2009).A contribuição das redes sociais para o desenvolvimento de projetos de pesquisa, desenvolvimento e inovação (P, D\&I): o caso da Embrapa Clima Temperado. Trabalho apresentado no SEGeT - Simpósio de Excelência em Gestão e Tecnologia. www.aedb.br/seget/artigos09/290_artigo.pdf [Acessed July 2I, 20II] 
NONAKA, I., Takeuchi, H. (1997). Criação de conhecimento na empresa: como as empresas japonesas geram a dinâmica da inovação. Rio de Janeiro: Campus.

O'REILLY, T. (2005). What Is Web 2.0: design patterns and business models for the next generation of software. O'Reilly Media, 2005. http://oreilly.com/web2/archive/whatis-web-20.html [Acessed July 2I, 20I I]

RECUERO, R. (2009). Redes sociais na internet. Coleção Cibercultura. Porto Alegre: Sulina.

RECUERO, R. C. (2004). Considerações sobre a Difusão de Informações em Redes Sociais na Internet. http://www.intercom.org.br/papers/regionais/sul2007/resumos/R0464-I. pdf [Acessed July 2I, 20II]

SILVA, M. C. M. (2003). Redes sociais intra-organizacionais informais e gestão. Dissertação (Mestrado em Administração). NPGA, UFBA: Salvador.

SOUZA, L. (2010). Redes sociais como proposta para amplificar a criação do conhecimento em organizações inovadoras. Dissertação (Mestrado) PPCGI. UFPR, Curitiba.

TOMAÉL, M. I.,Alcará,A. R., Di Chara, I. G. (2005). Das redes sociais à inovação. Revista Ciência da informação. Brasília, vol. $34, n^{\circ} .2$. mai/ago. p. 93-104.

TOMAÉL, M. I. (2005). Redes de Conhecimento: O Compartilhamento da Informação e do Conhecimento em Consórcio de Exportação do Setor Moveleiro. 289 p. Tese (Doutorado em Ciência da Informação) Escola de Ciência da Informação. UFMG, Belo Horizonte.

VASCONCELOS,V., Campos, P. (20I0). Distributed Informal Information Systems for Innovation: An Empirical Study of the Role of Social Networks. Centeris 2010 Proceedings, Part II, CCIS I I0, Springer; October 22.

VIANA, M. (2004). Redes sociais informais e compartilhamento de significados sobre mudança organizacional: estudo numa empresa petroquímica da Bahia. Dissertação (Mestrado em Psicologia) UFBA, Salvador.

VITAL, L.P.(2006). Fontes e canais de informação utilizados no desenvolvimento de sistemas em empresa de base tecnológica. Revista ACB: Biblioteconomia em Santa Catarina. Florianópolis, v.II, n.2, p. 297-3/3, ago./dez. http://revista. acbsc.org.br/index.php/racb/article/viewArticle/480/6/3. [Acessed July 2I, 20II]

WASSERMAN, S, Faust, K. (1994). Social network analysis: methods and applications. New York: Cambridge University Press.

\section{APPENDIX NOTES}

Among the cases of greatest impact we can highlight: the presidential campaign of Barack Obama, backed by an intense movement on the Internet, with information "minute by minute" by Twitter, achieved in 2008 , one of the biggest election turnout in the American history; the rapid mobilization of Brazilian society in the face of disaster caused by heavy rains in the state of Santa Catarina / Brazil in November 2008, which showed the speed and effectiveness of messages posted on social networks, especially Facebook and Twitter (Recuero, 2009).

The choice of these networks for the study is justified by its popularity in Brazil and lot of hits when the survey has been conducted. Due to the dynamic nature of the Internet and social networking, we recognize the importance that conquered other platforms later (like Google+ and ResearchGate, the social networking specific to researchers), but which were not subject of research in the period of data collection, according to court time.

Corporate portals have broadened their roles over time in the institutional scope, encompassing and presenting sectors, products and services of an organization, both to its customers and to its internal audience. However, this view has been very limited as we think about corporate portals geared towards effective knowledge generation and innovation promotion. The term "corporate" suggests, in essence, actions predominantly targeted to the interests of a single institution itself, the "owner" of the portal. However, the use of the traditional view to the implementation of an environment that aims to leverage innovative actions confirms the segmentation of the information and lack of cooperative activities within the system of $S$ \& T \& I National, where the keyword should be "integration". The purpose of the portal that is in development aims to overcome these barriers, adopting a more democratic and interactive positioning among several actors.

Araújo and Freire (1996) highlight that the networks and formal communication channels, especially periodicals, monographs, and databases have always been privileged in building the scientific knowledge. For scientific activity, the few informal channels considered were those represented by congresses, seminars, and similar events, in which annals are published

Formal social network is a series of links or ties between formal or standardized social positions. In general, to the scientific community they are established through the publication of monographs and periodicals. In contrast, informal social structures are not explained or prescribed by organizations and are based on interactions that depend on the

ISSN: 07 I8-2724. (http://www.jotmi.org)

Journal of Technology Management \& Innovation (c) Universidad Alberto Hurtado, Facultad de Economía y Negocios. 
personal attributes of the participants, who make voluntary choices.

The internet assumes both the characteristics of informal and formal sources, because it also brings content organized and structured - for example: the databases and published documents, which are available through service sharing or file transfer (Araújo Freire, 1996, and Vital , 2006).

One of the most cited is in the work of mathematician and geometer Leonhard Euler which originated the Graph Theory in the eighteenth century (Barabási, 2003). However, the systematic study of social networks appears only in the 1930's, when Jacob Moreno began the work that led to the sociometric approach and, together, the structural approach. (RECUERO, 2009)

The works of Jacob Moreno (Sociometry), Kurt Lewin (Field Theory), Fritz Heider (Theory of Attribution), and Cartwright and Harary (Graph Theory) stand out, with research on group structure and exchange information. The prevailing idea was that the objects are not perceived regardless of mental models, but constructed by them.

Anthropologists and sociologists from Harvard University studied the English social anthropologist Radcliffe-Brown. These studies emphasize the importance of informal interpersonal relationships in social systems and structures, which are broken down into subgroups in the networks that constitute them. In the 1920's, we highlight Elton Mayo and W. Lloyd Warner; in the 1940's, George Homans and his theoretical framework to explain group behavior based on sociometry and later during the 1950's and I960's, structural analysis mathematically oriented, highlighting the work of Harrison White and Granovetter in the 1970's. In the English university of Manchester, a research line developed studies, connecting math to social theory. Notably are the works of Max Gluckman, John Barnes, Elizabeth Bott, Siegfried Nadel and Clyde Mitchell (Viana, 2004).

Social Networking Analysis presupposes a trend analysis for the social role of the individual or group in a given context, where the movements and contacts are not random, but part of a dynamic process. In social network analysis, actors, their roles, and connections are observed. It is based on the observation that social actors are interdependent and that the connections between them have important consequences for the individual (Freeman, 1996). This methodology integrates elements of graph theory, allowing analysis of the network by means of matrices, charts or graphics. Among the available measures is the network density, the average clustering coefficient, and average distance. In this case, the centrality or proximity determining how the node that represents the actor is close to all other nodes or actors of the mapped network, having its base as the geodesic distance - which is the shortest path between two nodes, applied to directed graphs (Wasserman and Faust, 2004)

There are different forms of participation in virtual social networks. On the Internet, for example, you can "subscribe" to a mailing list or join a social group without interacting directly with its members, but only taking advantage of information circulating. You can also interact with a group of bloggers through comments and, with them, form a social network (RECUERO, 2003).

The social capital should not be confused with the human capital or with infrastructure. "Human capital includes the skills and knowledge of individuals who, together with other personal characteristics and effort expended, increase production possibilities and personal, social, and economic wellbeing" (MARTELETO and Silva, 2004, p 43).

According to Granovetter (1973), social ties can be weak or strong, a classification that can also be applied to those computer-mediated. Strong ties were those characterized by large investment of time, the creation of intimacy, trust and reciprocity. Weak ties, in contrast, have fewer of these elements, characterizing shallower relations, not translating closeness or intimacy, and only sparse relationships, with many social exchanges.

As noted by Donath (1999), the understanding of computer-mediated social interactions relates to the fact that networks and communication systems allow the creation of individual profiles in cyberspace. This customization is an essential element in the construction of identity, because the profiles allow actors to recognize themselves as individuals and interact, as the internet starts to work as a social space.

By using Google Trends (20I I), it is possible to note that Orkut has a declining trend in the number of hits from 2007 unlike Linkedln and Facebook that show a rise in the number of hits since 2010 and Twitter, with the number of accesses growing since 2009 .

The initial hypothesis was that if companies have the job of creating and maintaining an active institutional profile, they could also participate or promote in any way, in the exchange of technical and scientific knowledge in communities or groups, whose themes of interest would be identified in our search process.

In particular for the case of Twitter, simultaneously with the website's own search engine, the search engine SocialMention (Socialmention.com), which has a counter results was used. However, the counter SocialMention proved to be unreliable because merely displayed 100 results for some 
searches whereas the Twitter system indicated more than 100 results.

Vasconcelos and Campos (2010) observed the same situation, because in their research on marketing in social networks, particularly in Portugal, which included Orkut, Twitter, Linkedln, and Facebook among other social networks, Linkedln was the only professional social network existing that allowed more consistent mapping.

It was decided to have a control group created for comparison purposes. The option for the group of project management was based on the maturity of the group formed by experienced professionals who are part of an organization that is recognized as a world reference in project management, Project Management Institute (PMI).

The criterion used for the counting of the answered inquiries was only the existence of a response, the qualification of the answers was not taken into account. 